\title{
Matéria
}

ISSN 1517-7076

Revista Matéria, v. 15, n. 2, pp. 254-259, 2010.

http://www.materia.coppe.ufrj.br/sarra/artigos/artigo11226

\section{A general study of commercially pure Ti subjected to severe plastic deformation: microstructure, strength and corrosion resistance}

\author{
A.A. Mendes Filho; C.A. Rovere; S.E. Kuri; V.L. Sordi; M. Ferrante \\ Federal University of São Carlos, São Paulo, SP \\ e-mail: anibalmendes@gmail.com ; carlosdrovere@hotmail.com ; dsek@ufscar.br ; sordi@ufscar.br ; \\ ferrante@ufscar.br
}

\begin{abstract}
Bars of Titanium Grade 2 were subjected to deformation by Equal Channel Angular Pressing, both at room temperature and at $300^{\circ} \mathrm{C}$. Additionally, some specimens were cold rolled up to $70 \%$ reduction. From tensile tests, data such as yield, maximum strength, elongation and area reduction were obtained. Results show that the best strength - ductility combination is produced by four passes followed by cold rolling. Finally, the corrosion behavior was assessed following ASTM F2129 and no noticeable difference between the starting material and the ECAP-deformed was detected.
\end{abstract}

Keywords: Titanium, ECAP, strength, ductility, corrosion.

\section{INTRODUCTION}

Among the light metals Ti occupies a special place due to the association of three important characteristics: high strength, low density and high corrosion resistance. This material finds application in aerospace, chemical process equipment and more recently, thanks to its low elastic modulus, in medical implants. As for the last application it is customary to employ the Ti-6Al-4V alloy, but presently strong evidence regarding the potentially harmful effect on human health of $\mathrm{Al}$ and $\mathrm{V}$ motivated intense search for other solutions. Among those, the use of commercially pure Ti has the advantage of lower cost and higher corrosion resistance when compared to the standard alloy and to some others under development, which are based on $\mathrm{Nb}$ and $\mathrm{Zr}$ [1]; however the yield strength of commercial Ti is only $345 \mathrm{MPa}$ (Grade 2), whilst the $6-4$ alloy reaches $\approx 1000 \mathrm{MPa}$. As for ductility, it must be recalled that their total elongations are close to $28 \%$ and $10 \%$, respectively.

It is well known that the main effect of any severe plastic deformation (SPD) technique is strength enhancement due to grain size reduction to at least the submicrometer range. Thus, the application of any of those techniques to Ti may upgrade its tensile strength to levels acceptable for medical implants. On this respect, Equal Channel Angular Pressing (ECAP), from which sizeable products can be obtained, is expected to be the most viable technique. An additional advantage of producing a small grain size is the positive effect on osseointegration, that is, the ability of the implant surface to integrate with the adjacent bone and tissues [2] and also on fatigue strength [3] , an important requirement of bone replacement or repair products.

In most investigations concerning Ti and its alloys, SPD is followed by cold rolling (CR) $[\underline{4}, \underline{5}]$; normally the first step is performed at medium temperatures $\left(400-600^{\circ} \mathrm{C}\right)$ after a large number of ECAP passes. However, Zhao et al. [6] have demonstrated that room temperature deformation is possible, and suggested than this procedure is equivalent to warm multipass ECAP.

The present work deals with SPD of Ti Grade 2 subjected to ECAP- deformation, alone or followed by $\mathrm{CR}$. The main objective is to obtain tensile strength enhancement associated to reasonable ductility. Transmission electron microscopy (TEM) observation gave information on microstructural development, and data on comparative corrosion behavior is also presented. 


\subsection{Materials}

Commercial purity Grade $2 \mathrm{Ti}$ was supplied as extruded rods, which were subsequently annealed $\left(710^{\circ} \mathrm{C} / 2 \mathrm{~h}\right)$ and air cooled.

\subsection{ECAP- deformation}

Performed in a die $\left(\Phi=120^{\circ}\right.$ and $\left.\Psi=20^{\circ}\right)$ with $10 \mathrm{~mm}$ diameter channels. Heating was supplied by five resistance heaters embedded in the die and thermocouples were located close to the channel angle. Pressing was performed at 25 and $300^{\circ} \mathrm{C} \pm 20^{\circ} \mathrm{C}$ on $70 \mathrm{~mm}$ long billets, using $5 \mathrm{~mm} \mathrm{~min}^{-1}$ ram speed; Billets were subjected to one $(1 \mathrm{X})$ and four $(4 \mathrm{X})$ passes, following Route $\mathrm{B}_{\mathrm{C}}$. The warm-deformed samples are identified by adding the letter $\mathrm{H}$. Three billets $(0 \mathrm{X}, 1 \mathrm{XH}$ and $4 \mathrm{XH})$ were subjected to cold rolling (CR) up to $70 \%$ reduction without intermediate anneals.

\subsection{Characterization}

The microstructure was observed by TEM on planes parallel to the specimen axis (plane Y); samples were prepared in a TENUPOL3 equipment employing a 5 perchloric-95 acetic acid electrolyte. Vickers hardness measurements preceded tensile tests which were performed on sub size specimens $\left(8 \mathrm{~mm}^{2}\right.$ and $12 \mathrm{~mm}$ gauge length) at room temperature and strain rate equal to $10^{-3} \mathrm{~s}^{-1}$. The tensile parameters measured were $\sigma_{\mathrm{y}}, \sigma_{\mathrm{u}}, \varepsilon_{\mathrm{t}}$ (total elongation), $\varepsilon_{\mathrm{u}}$ (uniform elongation) and $\mathrm{S}$ (area reduction at fracture).

The corrosion behaviour was assessed by potentiodynamic polarization measurements carried out by adapting the ASTM G 5 and F 2129 standards. The electrolyte used was a 0.9 mass\% reagent-grade $\mathrm{NaCl}$ in distilled water, naturally aerated at $25^{\circ} \mathrm{C}$. An electrochemical cell composed of three electrodes was used with a Pt counter electrode and a saturated calomel reference electrode (SCE).

Polarization curves were obtained by the working electrode immersion in the electrolyte until a steady state corrosion potential, $\mathrm{E}_{\text {corr }}$, was reached $(\mathrm{t}>30 \mathrm{~min})$. A potentiodynamic sweep rate of $1 \mathrm{mV} / \mathrm{s}$ was used starting from $\mathrm{E}_{\text {corr }}$ to $800 \mathrm{mV}_{\mathrm{ECS}}$. To guarantee good reproducibility, a minimum of three curves per sample were performed.

\section{RESULTS AND DISCUSSION}

\subsection{Mechanical Behavior}

The engineering stress-strain curves of the six different conditions here produced, plus that of the extruded and annealed bar (initial condition) are shown in Figure 1. Comparison of samples 1X and 1XH shows that, although yield and maximum strength are virtually equal, the warm-deformed sample exhibits a much higher elongation. That is, $25 \%$ against $12 \%$. This indicates that ECAP-deformation at room temperature is not to be preferred over its warm counterpart, provided the pressing temperature is not too high. Analysis of the tensile behavior of these two different practices suggests that ECAP-deformation at $300^{\circ} \mathrm{C}$ caused very little grain growth but residual stresses were largely reduced. That temperature corresponds to a homologous temperature equal to 0.3 still insufficient for recrystallization. Also, from hot rolling studies of Grade $2 \mathrm{Ti}$, it was found that recrystallization hardly occurs below $600^{\circ} \mathrm{C}$ [7], hence, the benefit on ductility leaving almost unchanged the strength level, was due entirely to recovery.

A general comment on ductility regards the usefulness of its discrimination into uniform and nonuniform elongation, the former associated with work-hardening (W-H) behavior. On this respect, Table 1, besides containing the tensile data, includes the values of the parameter $\sigma_{\mathrm{u} /} \sigma_{\mathrm{y}}$, which is a measure of the W$\mathrm{H}$ capacity. A low value of this parameter is normally observed in SPD materials [ $[8]$, and the present results show that it decreases (from the undeformed state) more rapidly with ECAP than with CR. Figure 2 shows the increment of ultimate strength with respect to the undeformed material, brought about separately by ECAP and by CR; it is apparent that the former deformation method is more effective for raising strength. The maximum strength increment is $115 \%$, and is deployed by sample $4 \mathrm{XH}+\mathrm{CR}$; from Figure 2 it can be seen that almost $80 \%$ of said increment was given by ECAP. 




Figure 1: Engineering stress-strain curves of specimens deformed by ECAP and by ECAP+CR, compared to that of the extruded and annealed Grade $2 \mathrm{Ti}$.

Table 1: Tensile data of Ti Grade 2 in different conditions.

\begin{tabular}{l|c|c|c|c|c|c|c}
\hline \multicolumn{1}{c|}{ Sample } & $\begin{array}{c}\sigma_{\mathrm{y}} \\
(\mathrm{MPa})\end{array}$ & $\begin{array}{c}\sigma_{\mathrm{u}} \\
(\mathrm{MPa})\end{array}$ & $\begin{array}{c}\varepsilon_{\mathrm{u}} \\
(\%)\end{array}$ & $\begin{array}{c}\varepsilon_{\mathrm{t}} \\
(\%)\end{array}$ & $\begin{array}{c}\mathrm{S} \\
(\%)\end{array}$ & $\begin{array}{c}\text { Hardness } \\
(\mathrm{HV})\end{array}$ & $\sigma_{\mathrm{u}} / \sigma_{\mathrm{y}}$ \\
\hline $0 \mathrm{X}$ & 320 & 408 & 9.0 & 21 & 65 & 140 & 1.28 \\
\hline $0 \mathrm{X}+\mathrm{CR}$ & 585 & 702 & 2.5 & 17 & 62 & 236 & 1.20 \\
\hline $1 \mathrm{X}$ & 565 & 589 & 3.7 & 12 & 52 & 196 & 1.04 \\
\hline $1 \mathrm{XH}$ & 530 & 573 & 3.2 & 25 & 60 & 205 & 1.08 \\
\hline $4 \mathrm{XH}$ & 636 & 678 & 4.0 & 23 & 55 & 229 & 1.07 \\
\hline $1 \mathrm{XH}+\mathrm{CR}$ & 575 & 769 & 4.8 & 19 & 69 & 258 & 1.34 \\
\hline $4 \mathrm{XH}+\mathrm{CR}$ & 796 & 876 & 3.3 & 21 & 63 & 271 & 1.10 \\
\hline
\end{tabular}

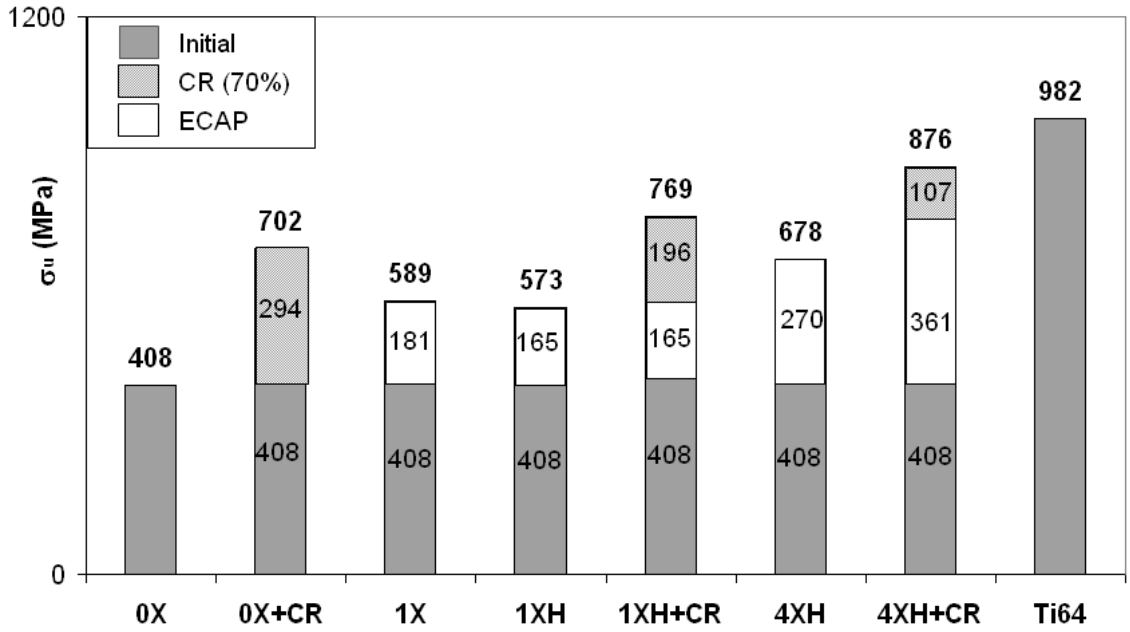

Figure 2: Ultimate strength increments caused by: (a) ECAP; (b) ECAP + CR.

Figure 3, besides showing the ultimate strength increments taken over the undeformed sample, summarizes the effect of ECAP and CR on total elongation. It can be seen that in some cases elongation is increased by ECAP; however, CR is always harmful, or at best is neutral, with $\Delta \varepsilon_{\mathrm{t}}=0$ for sample $4 \mathrm{XR}+\mathrm{CR}$. The larger ductility loss is shown by sample 1X; whilst the same one pass deformation but performed at $300^{\circ} \mathrm{C}$ gains a $13 \%$ advantage in terms of total elongation. 


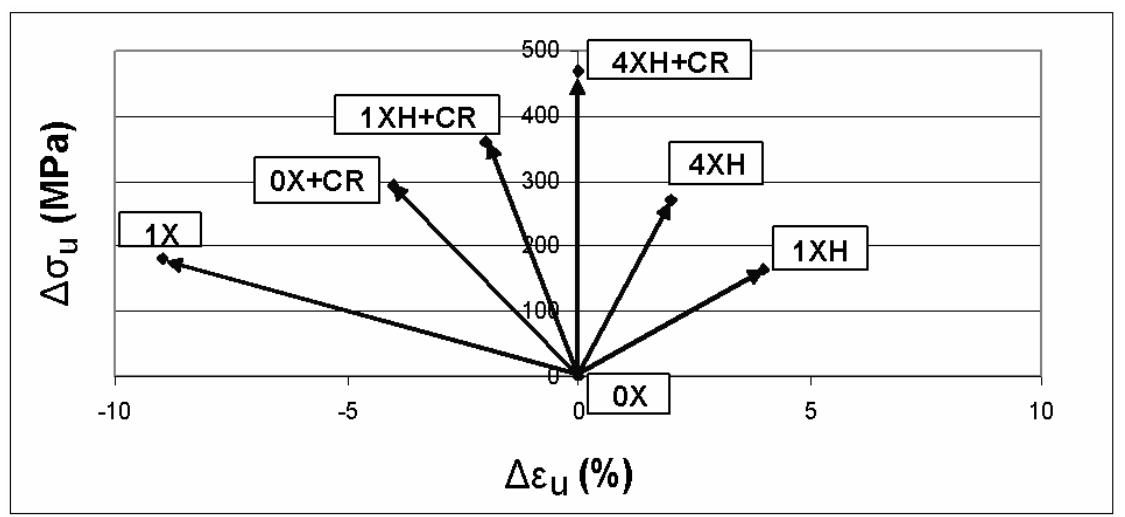

Figure 3: Increments and decrements of maximum strength and total elongation of the deformed samples, taken with respect to annealed Ti.

\subsection{Microstructure}

From Figure 4 it appears that most of the plastic deformation has been assisted by dislocations, thus twinning is not a relevant deformation mechanism.
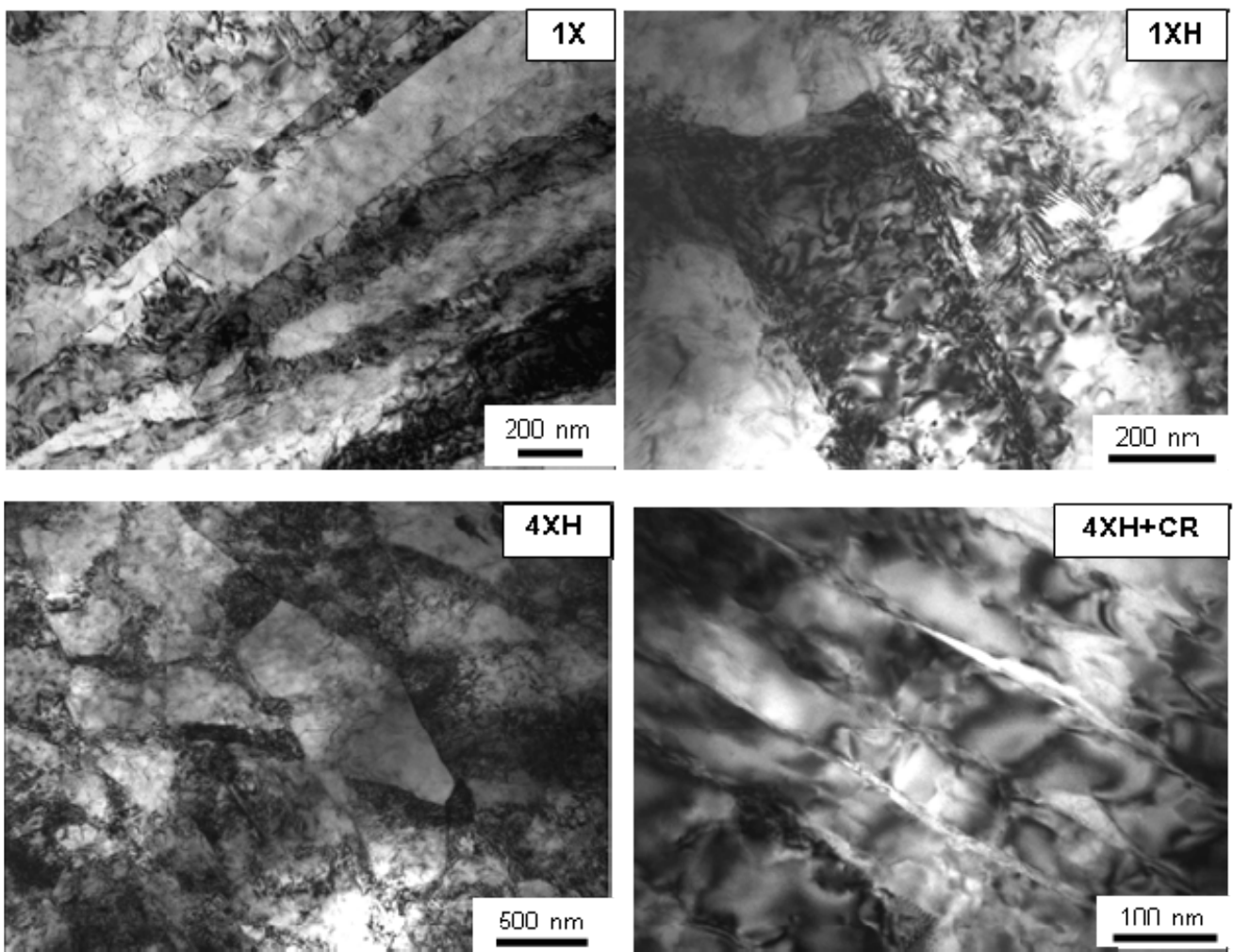

Figure 4: Transmission electron microscopy images of Ti deformed by ECAP and ECAP + CR.

This agrees with an experimental observation which concluded that dislocation- mediated deformation is dominant [9], complemented by a theoretical calculation on slip/twinning transition as a function of grain size [10]. The main difference between cold and warm ECAP - deformation seems to be the thickness of the elongated grains or sub-grains that is larger in the latter, compare microstructures of samples $1 \mathrm{X}$ and $1 \mathrm{XH}$ shown in Figure 4. After 4 passes an equiaxed grain structure is visible, although the microstructure is very heterogeneous. Adding CR, further deformation occurs and very thin $(<100 \mathrm{~nm})$ elongated grains are formed.

Finally, Figure 5 shows the anodic polarization curves of titanium in $0.9 \% \mathrm{NaCl}$ solution at $25^{\circ} \mathrm{C}$. The $0 \mathrm{X}, 1 \mathrm{X}$ and $4 \mathrm{XH}$ samples display a very similar anodic behavior with a high passivation potential range 
and a low current density of about $10^{-6} \mathrm{~A} / \mathrm{cm}^{2}$. Furthermore, the samples did not show an active-passive transition or a sharp and sudden rise in the current density that could be attributed to the nucleation and propagation of pits.

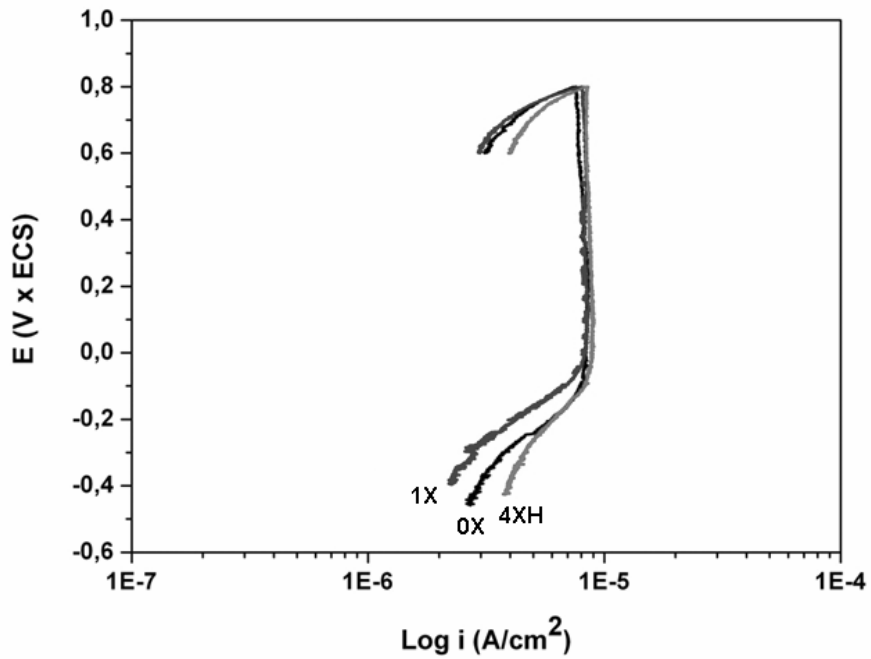

Figure 5: Anodic polarization curves of the samples, measured in a $0.9 \% \mathrm{NaCl}$ solution at $25^{\circ} \mathrm{C}$.

\section{CONCLUSIONS}

1. The strength difference between the 6-4 alloy and Grade $2 \mathrm{Ti}$ is reduced from $574 \mathrm{MPa}$ to 106 $\mathrm{MPa}$, by four ECAP passes at $300 \mathrm{oC}$, followed by CR.

2. In terms of strength increase, a 70\% thickness reduction by $\mathrm{CR}$ is equivalent to four warm ECAP passes. However, the former method reduces ductility, or at best leaves it unchanged, whilst warm ECAP always increases that property.

3. Analysis of the stress - strain curves and tensile data showed that warm ECAP gives excellent combination of strength and ductility. The best performance in this sense is exhibited by sample $4 \mathrm{XH}+\mathrm{CR}$ : strength was increased by $115 \%$ without any ductility loss with respect to the undeformed material.

4. TEM observation found very little evidence of twins, thus most of the deformation was dislocation - assisted.

5. The conventional anodic behavior of annealed Grade 2 Ti was not changed by SPD.

\section{REFERENCES}

[1] GEETHA, M., SINGH, A.K., ASOKAMANI, R., GOGIA, A.K., "Ti based biomaterials, the ultimate choice for orthopaedic implants - A review", Progress in Materials Science, v. 54, n. 3, pp. 397-425, 2009.

[2] PARK, J.W., KIM, Y-J., PARK, C.H., LEE, D-H., KO, Y.G., JANG, J-H., LEE, C.S., "Enhanced osteoblast response to an equal channel angular pressing-processed pure titanium substrate with microrough surface topography", Acta Biomaterialia, v. 5, pp. 3272 - 3280, 2009.

[3] VALIEV, R.Z., STOLYAROV, V.V., RACK, H.J., LOWE, T.C., In: S. Shrivastava Ed., Medical Device Materials, ASM, Cleveland, OH, pp. 362, 2004.

[4] STOLYAROV, V.V., ZHU, Y.T., ALEXANDROV, I.V., LOWE, T.C., VALIEV, R.Z., "Grain refinement and properties of pure Ti processed by warm ECAP and cold rolling”, Materials Science and Engineering A, v. 343, pp. 43-50, 2003.

[5] FAN, Z., JIANG, H., SUN, X., SONG, J., ZHANG, X., XIE, C., "Microstructures and mechanical deformation behaviors of ultrafine-grained commercial pure (grade 3) Ti processed by two-step severe plastic deformation", Materials Science and Engineering A, v. 527, n.1-2, pp. 45-51, December 2009. 
[6] ZHAO, X., FU, W., YANG, X., LANGDON, T.G., "Microstructure and properties of pure titanium processed by equal-channel angular pressing at room temperature", Scripta Materialia, v. 59, n. 5, pp. 542-545, September 2008.

[7] HAYASHI, M., YOSHIMURA, H., ISHII, M., HARADA, H., Nippon Steel Technical Report No6, UDC669.295 -174:621.7.061.2, 1994.

[8] WANG, Y.M., MA, E., "Strain hardening, strain rate sensitivity, and ductility of nanostructured metals", Materials Science and Engineering A, v. 375-377, pp. 46-52, July 2004.

[9] CHEN, Y.J., LI, Y.J., WALMSLEY, J.C., DUMOUliN, S., SKARET, P.C., ROVEN, H.J., "Microstructure evolution of commercial pure titanium during equal channel angular pressing", Materials Science and Engineering A, v. 527, n. 3, pp. 789-796, January 2010.

[10] MEYERS, M.A., BENSON, D.J., VÖHRINGER, O., KAD, B.K., XUE, Q., FU, H-H., "Constitutive description of dynamic deformation: physically-based mechanisms", Materials Science and Engineering A, v. 322, pp. 194-216, 2002. 